ScIDice

\section{Association between Temporomandibular Disorders with Head and Neck Posture: A Systematic Review}

Raquel Delgado-Delgado ${ }^{1,2}$, Almudena Martínez-Conesa ${ }^{1,3}$, Juan Antonio Valera-Calero ${ }^{1 *}$, Sofía Olivia Calvo-Moreno ${ }^{1,2}$, Gracia María Gallego-Sendarrubias $^{1}$, María Belén Centenera-Centenera ${ }^{4}$

${ }^{1}$ Department of Physiotherapy, Faculty of Health, Universidad Camilo José Cela, Villanueva de la Cañada, Madrid, Spain.

${ }^{2}$ Escuela Internacional de Doctorado, Universidad Camilo José Cela, Villanueva de la Cañada, Madrid Spain.

${ }^{3}$ Private Professional Practice, Madrid, Spain.

${ }^{4}$ Clinic of Orthodontics, Faculty of Dentistry, Universidad Alfonso X el Sabio, Madrid, Spain.

\title{
Abstract
}

Purpose: To systematically review the association of head and neck posture features with TMD. A systematic searchfor observational studies evaluating head and neck postural control features in patients with TMD diagnosis according to DC/TMD or RDC/ TMD criteria was conducted.

Methods: Data were extracted by two reviewers according to the STARLITE guidelines. The methodological quality was assessed with a specific 8 -items questionnaire.

Results: Nine studies were included with a methodological quality ranging from 4 to 7 (mean: 5.3; SD: 1.0), four using photogrammetry and six using radiography assessments. Craniocervical angle, distance between vertebral segments, hyoid bone position, high cervical angle, low cervical angle,the anterior translation angle, lordosis angle, and craniocervical mobility index were assessed. Craniocervical angle, hyoid position, and C0-C1-C2 distance are not associated with TMD. More high-quality with proper TMD diagnostic criteria, sample size and valid/reliable procedures are needed to confirm the association between TMD with disc displacement, ANB angle, and cervical lordosis.

Keywords: Temporomandibular Disorders; Posture; Craniocervical Angle; Temporomandibular Joint; Systematic Review.

\section{Introduction}

The analysis of the postural control has been demonstrated to play a relevant role for the maximal mouth opening, pressure pain thresholds and musculoskeletal pain $[1,2]$. Stabilometry and head and neck postures aredifferent methods for assessingpostural control. In fact, stabilometry is a valid tool in the postural approach of temporomandibular disorders (TMD) [3]. Nevertheless, an unclear association between temporomandibular disorders (TMD) and head and cervical posturehas been reported due to the poor methodological quality of the studies assessed [4].

TMD are a heterogeneous group of conditions affecting the temporomandibular joints (TMJ), the jaw muscles and/or the related structures [5]. TMD is a significant public health problem affect- ing the $5-12 \%$ of the entire population, being the second most common musculoskeletal condition after chronic low back pain resulting in pain and disability with a high economic impact $\$ 4$ billion in USA) [6]. Patients are clinically characterized by muscular or joint orofacial pain, limited range of mandibular movement, headache, ear pain, chewing difficulties or pain, and clicking [7].

An important stepto diagnose properly a TMD is to stablish clear, reliable, and valid criteria. The Diagnostic Criteria for TMD (DC/ TMD) and the Research Diagnostic Criteria for Temporomandibular Disorders (RDC/TMD) have been the most widely employed diagnostic protocolduring the clinical practice and showed a sensitivity $\geq 0.86$, specificity $\geq 0.98$, an acceptable inter-examiner reliability (kappa $\geq 0.85$ ) and is appropriate for use in both clinical and research settings [8].

\section{*Corresponding Author:}

Juan Antonio Valera Calero,

Department of Physiotherapy, Faculty of Health, Universidad Camilo José Cela, Villanueva de la Cañada, Madrid, Spain.

Tel: (+34) 653766841

E-mail: javaleracalero@gmail.com

Received: November 30, 2020

Accepted: December 28, 2020

Published: January 08, 202

Citation: Raquel Delgado-Delgado, Almudena Martínez-Conesa, Juan Antonio Valera-Calero, Sofía Olivia Calvo-Moreno, Gracia María Gallego-Sendarrubias, María Belén Centenera-Centenera. Association between Temporomandibular Disorders with Head and Neck Posture: A Systematic Review. Int J Dentistry Oral Sci. 2021;8(1):1314-1319. doi: http:// dx.doi.org/10.19070/2377-8075-21000260

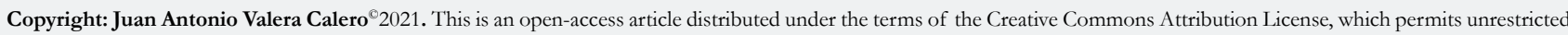
use, distribution and reproduction in any medium, provided the original author and source are credited. 
To the best of our knowledge, the last systematic review investigating the association between TMD and head posture was conducted in 2013 by Rocha et al., [9], reporting an insufficient number of articles with acceptable methodological quality. Therefore, the current systematic review updates the information about the association between TMD and head posture.

\section{Methods}

This systematic review adheres to the Preferred Reporting Items for Systematic Reviews and Meta-Analyses (PRISMA) statement [10]. The international OPS Registry registration link is http:// doi.org/10.17605/OSF.IO/WZE5A.

\section{Data Sources}

Electronic literature searches were conducted on MEDLINE, PubMed, SCOPUS and Web of Science databases between January 2010 and December 2019. Bibliographical search strategies were conducted with the assistance of an experienced health science librarian and following the guidelines described by Greenhalgh [11]. Search strategies were based on a combination of Meshterms/key words following the PICO(Population, Intervention, Comparison, Outcome) question:

Population: Adults (older than 18 years old) withTMD

Intervention: Use of DC/TMD or RDC/TMD criteria for TMD diagnosis.

Comparator: Healthy population.

Outcomes: The quantification ofhead posture.

An example of the search strategy (PubMed database)was as follows:

Filters: [Title/Abstract]

\#1 Temporomandibular Joint Disorders[Mesh]

\#2Temporomandibular disorders

\#3Temporomandibular dysfunction

\#4\#1 OR \#2 OR \#3

\#5Posture[Mesh]

\#6 Postural balance

\#7 Postural control

\#8 Head posture

\#9 Neck posture

\#10 Craniocervical angle

\#11 \#5 OR \#6 OR \#7 OR \#8 OR \#9 OR \#10

\section{Study Eligibility Criteria}

Studies were eligible for inclusion if they evaluate the head and neck postural controlin adults with TMDand were published in the English language. Animal studies, cadaveric studies, published proceedings, and abstracts and articles including patients under orthodontic treatment were excluded.

\section{Study Appraisal and Synthesis Methods}

The Mendeley Desktop v.1.19.4 for Mac OS (Glyph \& Cog, LLC 2008)program was used to insert the search hits from the databases. First, the duplicates were removed. Second, title/abstracts of the articles were screened for potential eligibility by two authors.
Third, the fulltext was analyzed to identify potentially eligible studies. Reviewers were required to achieve a consensus. In case of discrepancy between both reviewers, a third reviewer participated in the process to reach the consensus for including or not including the study.

A standardized data extraction form containing questions on sample population, methodology, results, and outcomes was used, according to the STARLITE guideline [12]. We specifically assessed the methodology used to evaluate the postural control and the reliability and validity of the method used.

The methodological quality of the included studies was assessed based on a previous checklist proposed by Olivo et al., [4]. This methodological scale for observational studies assessing the correlation between temporomandibular disorders with craniocervical angleconsists of 8 items focusing on the assessor blinding, the sample size, the use of standardized criteria for TMD diagnosis, the report of at least the $80 \%$ of participants, enough procedures and assessment information, clear data analysis statement, and statements about the validity and reproducibility of the measuring instrument or procedure. Higher score represents higher quality of the study.

\section{Results}

\section{Study Selection}

The electronic searches identified 475 potential studies for review. After removing duplicates, 342 studies remained. Two hundred and thirty-five $(n=235)$ studies were excluded based on examination of their titles or abstracts, leaving 107 articles for full-text analysis. Ninety-eight articles were excluded because they did not use DC/TMD or RDC/TMD criteria for TMD diagnosisor they did not assess head nor neck posture. A total of nine studies were included in the systematic review [13-21]. Six studies assessed the head and neck posture by using a radiographic analysis [13, 16$18,20,21]$ and four studies by using a photogrammetric analysis $[14,15,18,19]$. In addition, one study included a baropodometry asessesment [14] (Figure 1).

\section{Methodological Quality}

The methodological quality scores ranged from 4 to 7 (mean: 5.3, SD: 1.0 ) out of a maximum of 8 points (Table 1 ). The most consistent flaws were sample size (just 3 studies stated a representative sample estimation), absence of information about the validity or reliability of the procedures selected for the assessment (just 3 studies include validity information and 5 include reliability information) and no blinding of the assessor ( 5 studies blinded the assessor. Methodological quality of studies which usedradiographic analysis (mean \pm SD: $5.16 \pm 0.75$ ) was slightly inferior to photogrammetric analysis (mean \pm SD: $5.25 \pm 1.50$ ).

\section{Data extraction}

Table 2 summarizes the 9 studies investigating the association between head and neck posture with TMD. The number of studies assessing head and neck posture were balanced in the instrument selection: photogrammetry $(n=4)$ and radiography $(n=6)$. Further, onestudy investigated the balance [13]. The nine studies in- 
Figure 1. Preferred Reporting Items for Systematic reviews and Meta-Analyses(PRISMA) Flowchart.



Table 1. Methodological Quality Assessment of the included studies.

\begin{tabular}{|c|c|c|c|c|c|c|c|c|c|}
\hline STUDY & $\begin{array}{l}\text { Blinding } \\
\text { assessor }\end{array}$ & $\begin{array}{l}\text { Repre- } \\
\text { sentative } \\
\text { sample }\end{array}$ & $\begin{array}{l}\text { RDC/ } \\
\text { TMD }\end{array}$ & $\begin{array}{c}\text { Data } \\
80 \% \text { of } \\
\text { cohort } \\
\text { reported }\end{array}$ & $\begin{array}{l}\text { Reproducibil- } \\
\text { ity: sufficient } \\
\text { information } \\
\text { reported }\end{array}$ & $\begin{array}{c}\text { Data } \\
\text { analyses } \\
\text { clearly } \\
\text { defined }\end{array}$ & $\begin{array}{l}\text { Valid- } \\
\text { ity of the } \\
\text { measuring } \\
\text { instrument }\end{array}$ & $\begin{array}{l}\text { Reliabil- } \\
\text { ity of the } \\
\text { measuring } \\
\text { instrument }\end{array}$ & SCORE \\
\hline $\begin{array}{c}\text { Barbosa et } \\
\text { al. [13] }\end{array}$ & Y & $\mathrm{N}$ & Y & Y & $\mathrm{Y}$ & Y & $\mathrm{N}$ & Y & $6 / 8$ \\
\hline $\begin{array}{c}\text { Souza et } \\
\text { al.[14] }\end{array}$ & Y & $\mathrm{N}$ & $\mathrm{N}$ & Y & $\mathrm{Y}$ & Y & $\mathrm{Y}$ & $\mathrm{Y}$ & $6 / 8$ \\
\hline $\begin{array}{c}\text { Ferreira et } \\
\text { al. }[15]\end{array}$ & Y & Y & $\mathrm{Y}$ & Y & Y & $\mathrm{Y}$ & $\mathrm{N}$ & Y & $7 / 8$ \\
\hline $\begin{array}{c}\text { de Farias } \\
\text { Netoet } \\
\text { al.[16] }\end{array}$ & Y & $\mathrm{N}$ & Y & $\mathrm{N}$ & Y & Y & Y & $\mathrm{N}$ & $5 / 8$ \\
\hline $\begin{array}{c}\text { Matheus et } \\
\text { al. [17] }\end{array}$ & $\mathrm{Y}$ & $\mathrm{N}$ & Y & Y & $\mathrm{Y}$ & $\mathrm{Y}$ & $\mathrm{N}$ & Y & $6 / 8$ \\
\hline $\begin{array}{c}\text { Sadduet al. } \\
{[18]}\end{array}$ & $\mathrm{N}$ & Y & $\mathrm{N}$ & Y & Y & $\mathrm{Y}$ & $\mathrm{N}$ & $\mathrm{N}$ & $4 / 8$ \\
\hline $\begin{array}{c}\text { Di Giacomo } \\
\text { et al. [19] }\end{array}$ & $\mathrm{N}$ & $\mathrm{N}$ & $\mathrm{N}$ & Y & $\mathrm{Y}$ & $\mathrm{Y}$ & $\mathrm{Y}$ & $\mathrm{N}$ & $4 / 8$ \\
\hline $\begin{array}{c}\text { Weber et } \\
\text { al.[20] }\end{array}$ & $\mathrm{N}$ & $\mathrm{N}$ & $\mathrm{Y}$ & Y & $\mathrm{Y}$ & Y & $\mathrm{N}$ & Y & $5 / 8$ \\
\hline $\begin{array}{c}\text { Rakesh et al. } \\
{[21]}\end{array}$ & $\mathrm{N}$ & $\mathrm{Y}$ & $\mathrm{Y}$ & Y & Y & $\mathrm{Y}$ & $\mathrm{N}$ & $\mathrm{N}$ & $5 / 8$ \\
\hline
\end{tabular}

Y: Yes; N: No

volved a total sample of 490 subjects (100 men and 390 women), where 230 were patients with TMD ( 22 had TMD and migraine). In addition to the radiographic studies which assessed the craniocervical angle [13, 16-21], three studies assessed the distance between $\mathrm{C} 0-\mathrm{C} 1[13,17,21]$; one the $\mathrm{C} 1-\mathrm{C} 2$ [17] distance;three assessed thehyoid bone position [13, 17, 19]; one study assessed the craniocervical mobility index, forward head posture angle and cervical lordosis angle [20]; and one study assessed specifically the high cervical angle, the low cervical angle, and the anterior translation angle [21].

All the studies which used photogrammetry assessed only the craniocervical angle $[14,15,18,19]$, but one which also assessed the lumbar lordosis difference between patients with TMD and 
Table 2. Characteristics and main results of the studies included in the review.

\begin{tabular}{|c|c|c|c|c|c|}
\hline Study & Demographics & Aim & \begin{tabular}{|c|} 
Criteria used \\
for assess- \\
ment/diagno- \\
sis TMD \\
\end{tabular} & $\begin{array}{l}\text { Method used to assess } \\
\text { body posture }\end{array}$ & Results \\
\hline $\begin{array}{c}\text { Barbosa } \\
\text { et al. } \\
\text { [13] }\end{array}$ & $\begin{array}{c}\text { Total sample } \mathrm{n}=80 \\
54 \mathrm{~F} / 16 \mathrm{M} \\
\text { Age: } 18-26 \\
\text { TMD Group }(\mathrm{n}=28) \\
\text { Not TMD Group } \\
(\mathrm{n}=52)\end{array}$ & $\begin{array}{l}\text { To evaluate the relation- } \\
\text { ship between TMD and } \\
\text { craniocervical posture in } \\
\text { the sagittal plane measured } \\
\text { from lateral radiographs of } \\
\text { the head. }\end{array}$ & $\begin{array}{c}\text { RDC/TMD + } \\
\text { physical exami- } \\
\text { nation of the } \\
\text { TMJ. }\end{array}$ & $\begin{array}{l}\text { Radiographic analysis: } \mathrm{OAD} \text {, } \\
\mathrm{CCA} \text { and hyoid bone position }\end{array}$ & $\begin{array}{l}\text { TMD Group: } 62 \% \text { presented modifications in } \\
\text { the position of the hyoid bone, } 47.5 \% \text { presented } \\
\text { alterations in the CCA and } 42 \% \text { showed an ante- } \\
\text { rior positioning of the head, but these measure- } \\
\text { ments did not show an association with TMD, } \\
\text { nor was there statistically significant differences } \\
\text { between the groups with or without TMD. }\end{array}$ \\
\hline $\begin{array}{c}\text { Souza et } \\
\text { al.[14] }\end{array}$ & \begin{tabular}{|c|} 
Total sample $\mathrm{n}=51$ \\
$48 \mathrm{~F} / 3 \mathrm{M}$ \\
TMD Group: $\mathrm{n}=21 ;$ \\
20F/1M; mean age: 25 \\
Not TMD \\
Group: $\mathrm{n}=30 ;$ \\
28F/2M; mean age: 22
\end{tabular} & $\begin{array}{l}\text { To evaluate body posture } \\
\text { and the distribution of } \\
\text { plantar pressure at physi- } \\
\text { ologic rest of the mandible } \\
\text { and during maximal inter- } \\
\text { cuspal positions in subjects } \\
\text { with and without TMD. }\end{array}$ & RDC/TMD & $\begin{array}{l}\text { Postural evaluation (SAPO } \\
\text { software version } 0.68 \text { ) for } \\
\text { photogrammetric analysis }+ \\
\text { camera (Sony Cysbershot } 4.1 \\
\text { Mpx)Plantar pressure distri- } \\
\text { bution by baropodometry } \\
\text { (Footwork; STI-AM3, France) }\end{array}$ & $\begin{array}{l}\text { Photogrammetric analysis: both groups showed } \\
\text { body imbalances, but in the TMD group: pro- } \\
\text { nounced cranio-cervical distance, right calcaneal } \\
\text { valgus and greater inclination of the pelvis. } \\
\text { Baropodometry analysis: abnormal plantar } \\
\text { pressure distribution. Misalignment of the body } \\
\text { was found in both groups, but the changes were } \\
\text { more pronounced in the TMD group. } \\
\end{array}$ \\
\hline $\begin{array}{c}\text { Ferreira } \\
\text { et al. } \\
{[15]}\end{array}$ & $\begin{array}{c}\text { Total sample } \mathrm{n}=66 \\
66 \mathrm{~F} \\
\text { MG+TMD Group: } \\
\mathrm{n}=22 \mathrm{~F} ; \text { mean age: } \\
30,27 \\
\text { MG Group: } \mathrm{n}=22 \mathrm{~F} ; \\
\text { mean age: } 31,72 \\
\text { Control Group: } \\
\mathrm{n}=22 \mathrm{~F} ; \text { mean age: } \\
24,41 \\
\end{array}$ & $\begin{array}{l}\text { To detect changes in static } \\
\text { body posture in patients } \\
\text { with migraine in the pres- } \\
\text { ence or absence of TMD } \\
\text { when compared to CG. }\end{array}$ & $\begin{array}{c}\text { RDC/TMD + } \\
\text { Migraine diag- } \\
\text { nostic according } \\
\text { to the criteria } \\
\text { set by the } \\
\text { International } \\
\text { Classification } \\
\text { of Headache } \\
\text { Disorders }\end{array}$ & $\begin{array}{l}\text { Postural evaluation by pho- } \\
\text { togrammetry (Canon Rebel } \\
\text { EOS-300 digital camera). } \\
\text { Image analysis: Corporis Pro } \\
3.1 \text { (Data Hominis technol- } \\
\text { ogy, Brazil) }\end{array}$ & $\begin{array}{l}\text { Significant differences between the MG+TMD } \\
\text { group and the MG group in facial symmetry } \\
\text { and head tilt angles. The mean angle of lumbar } \\
\text { lordosis was significantly higher in the MG and } \\
\text { MG+TMD groups than in the CG.The results } \\
\text { demonstrated changes in the body posture of } \\
\text { women with migraine with or without TMD, } \\
\text { compared to CG. Such postural changes were } \\
\text { similar between the MG and MG+TMD groups. }\end{array}$ \\
\hline $\begin{array}{c}\text { de } \\
\text { Farias } \\
\text { Netoet } \\
\text { al.[16] }\end{array}$ & $\begin{array}{l}\text { Total sample } \mathrm{n}=23 \\
14 \mathrm{~F} / 9 \mathrm{M} \\
\text { TMD Group: } \mathrm{n}=12 \text {; } \\
\text { 7F/5M; mean age: } \\
22,5 \\
\text { Not TMD Group: } \\
\mathrm{n}=11 ; 7 \mathrm{~F} / 4 \mathrm{M} ; \text { mean } \\
\text { age: } 20\end{array}$ & $\begin{array}{c}\text { To compare the crani- } \\
\text { ocervical posture between } \\
\text { TMD patients and subjects } \\
\text { without TMD. }\end{array}$ & RDC/TMD & $\begin{array}{c}\text { Craniocervical posture evalua- } \\
\text { tion by radiographic examina- } \\
\text { tion in the sagittal plane to } \\
\text { determine different angles } \\
\text { and distances (HCA, LCA, } \\
\text { APA, OAD, ATD) }\end{array}$ & $\begin{array}{l}\text { There were no significant differences between } \\
\text { the groups for HCA, LCA and OAD. Measure- } \\
\text { ment of APA was higher in the TMD Group } \\
\text { than in the Not TMD Group. The anterior } \\
\text { translation distance was significant in the TMD } \\
\text { Group. } \\
\text { This suggests a tendency for subjects with TMD } \\
\text { to present with cervical hyperlordosis. } \\
\end{array}$ \\
\hline $\begin{array}{l}\text { Matheus } \\
\text { et al. } \\
{[17]}\end{array}$ & $\begin{array}{c}\text { Total sample } \mathrm{n}=60 \\
47 \mathrm{~F} / 13 \mathrm{M} \\
\text { Mean age: } 34,2 \\
\text { TMD Group }(\mathrm{n}=30) \\
\text { Not TMD Group } \\
(\mathrm{n}=30)\end{array}$ & \begin{tabular}{|c|} 
To evaluate the possibility \\
of any correlation between \\
disc displacement and \\
parameters used for evalu- \\
ation of skull positioning \\
in relation to the cervical \\
spine: craniocervical angle, \\
suboccipital space between \\
C0-C1, cervical curvature \\
and position of the hyoid \\
bone in individuals with \\
and without symptoms of \\
TMD. \\
\end{tabular} & $\begin{array}{c}\text { RDC/TMD + } \\
\text { MRI and telera- } \\
\text { diography. }\end{array}$ & $\begin{array}{l}\text { Lateral teleradiographs- ceph- } \\
\text { alometric analysis to measure } \\
\text { distance } \mathrm{C} 0-\mathrm{C} 1, \mathrm{C} 1-\mathrm{C} 2, \mathrm{CCA} \\
\text { and hyoid bone position. }\end{array}$ & $\begin{array}{l}\text { Group TMD: disc displacement, normal suboc- } \\
\text { cipital space. } \\
\text { NonTMD group: no disc displacement, normal } \\
\text { values of space C0-C1. } \\
\text { Significant differences between the position of } \\
\text { the disc and the C0-C1 space for subjects with } \\
\text { TMD ( } \mathrm{p}=0.04) \text { and without TMD }(\mathrm{p}=0.02) \text {. } \\
\text { No differences for the C1-C } 2 \text { space, CCA and } \\
\text { hyoid bone position. }\end{array}$ \\
\hline $\begin{array}{c}\text { Sadduet } \\
\text { al.[18] }\end{array}$ & $\begin{array}{c}\text { Total sample } \mathrm{n}=34 \\
19 \mathrm{~F} / 15 \mathrm{M} \\
\text { Mean age: } 18-50 \\
\text { Group I (TMD/disor- } \\
\text { der muscle subgroup): } \\
\mathrm{n}=17 \\
\text { Group II (TMD } / \text { disc } \\
\text { displacement): } \mathrm{n}=17 \\
\text { Control Group (not } \\
\text { TMD) } \mathrm{n}=34\end{array}$ & $\begin{array}{c}\text { To evaluate head and } \\
\text { craniocervical posture } \\
\text { among individuals with } \\
\text { and without TMD and its } \\
\text { subtypes by photographic } \\
\text { and radiographic method. }\end{array}$ & RDC/TMD & $\begin{array}{c}\text { Photographic analysis, (Sony } \\
\text { Cyber-shot } 7.2 \text { Mpx camera), } \\
\text { craniocervical posture-radi- } \\
\text { ographic analysis, (Planmeca } \\
\text { Prolin XC) head posture and } \\
\text { spine- analysis of CCA } \\
\text { changes (Planmeca Romexis } \\
\text { 2.1.1.R software) }\end{array}$ & $\begin{array}{c}\text { Photographic head posture angle and radio- } \\
\text { graphic CCA showed no statistically significant } \\
\text { difference ( } \mathrm{p}>0.05 \text { ) between Group I, Group II } \\
\text { and CG. } \\
\text { However, statistically significant difference was } \\
\text { noted with C1-C2 distance among Group II } \\
\text { ( } \mathrm{p}=0.001 \text { ) and cervical curvature angle among } \\
\text { Group I ( } \mathrm{p}=0.045 \text { ) individuals. } \\
\text { There is no relationship between head posture } \\
\text { and TMD, but they do suggest that the muscular } \\
\text { component plays an important role in TMD } \\
\text { production, since there is a positive relationship } \\
\text { between cervical posture and TMD. }\end{array}$ \\
\hline $\begin{array}{c}\text { Giaco- } \\
\text { mo et al. } \\
{[19]}\end{array}$ & $\begin{array}{c}\text { Total sample } \mathrm{n}=59 \\
\text { 38F/21M } \\
\text { Mean Age: } 33,65 \\
\text { TMD Group: } \mathrm{n}=26 \text {; } \\
\text { 24F/2M; mean age: } \\
\text { 44,69 } \\
\text { Not TMD Group: } \\
\mathrm{n}=33 ; 14 \mathrm{~F} / 19 \mathrm{M} ; \\
\text { mean age }\end{array}$ & $\begin{array}{c}\text { To assess changes in the } \\
\text { craniocervical structure } \\
\text { and in hyoid bone position } \\
\text { in skeletal Class II subjects } \\
\text { with and without TMD. }\end{array}$ & RDC/TMD & $\begin{array}{l}\text { Lateral teleradiographs-ceph- } \\
\text { alometric analysis to measure } \\
\text { distance } \mathrm{C} 0-\mathrm{C} 1, \mathrm{C} 1-\mathrm{C} 2, \mathrm{CCA} \\
\text { and hyoid bone position. }\end{array}$ & $\begin{array}{l}\text { C0-C1 and C1-C2 distance values and hyoid } \\
\text { bone position resulted within the normal range } \\
\text { in the majority of patients examined. CCA was } \\
\text { altered in } 33 \text { patients. The reduction of this an- } \\
\text { gle with the increase of the ANB value resulted } \\
\text { to be statistically significant in TMD Group. No } \\
\text { other data were statistically significant. }\end{array}$ \\
\hline
\end{tabular}




\begin{tabular}{|c|c|c|c|c|c|}
\hline $\begin{array}{c}\text { We- } \\
\text { ber et } \\
\text { al. }[20]\end{array}$ & $\begin{array}{c}\text { Total sample } \mathrm{n}=71 \\
71 \mathrm{~F} \\
\text { TMD Group (G1): } \\
\text { n=34F; mean age: } 23,4 \\
\text { Not TMD Group } \\
\text { (G2): } \mathrm{n}=34 \mathrm{~F} \text {; mean } \\
\text { age: } 23,8\end{array}$ & $\begin{array}{l}\text { To study the frequency } \\
\text { of cervical spine dysfunc- } \\
\text { tion (CCD) signs and } \\
\text { symptoms in subjects with } \\
\text { and without TMD and to } \\
\text { assess the craniocervical } \\
\text { posture influence on TMD } \\
\text { and CCD coexistence. }\end{array}$ & RDC/TMD & $\begin{array}{l}\text { CCDI evaluation, CMI exam } \\
\text { with fleximeter and CCA } \\
\text { evaluation with cephalomet- } \\
\text { ric analysis by radiography } \\
\text { (FHPA, CLA and CVA) }\end{array}$ & $\begin{array}{l}\text { G1 subjects presented a higher frequency of } \\
\text { moderate and severe CCD, as well as greater } \\
\text { neck pain, both in the palpation of the muscula- } \\
\text { ture and in the joint range of motion compared } \\
\text { to G2 subjects. } \\
\text { The craniocervical posture did not show signifi- } \\
\text { cant differences between groups, so it does not } \\
\text { suggest postural alterations related to CCD in } \\
\text { G1 subjects. }\end{array}$ \\
\hline $\begin{array}{c}\text { Rakesh } \\
\text { et al. } \\
{[21]}\end{array}$ & $\begin{array}{l}\text { Total sample } n=46 \\
\text { 23F } / 23 \mathrm{M} \\
\text { TMD Group: } \mathrm{n}=23 \text {; } \\
\text { 14F/9M; mean age: } \\
30,52 \\
\text { Control Group } \\
\text { (not TMD): } \mathrm{n}=23 \text {; } \\
\text { 14F/9M; mean age: } \\
29,9\end{array}$ & $\begin{array}{l}\text { To compare cervical spine } \\
\text { radiographs of TMD sub- } \\
\text { jects with those of healthy } \\
\text { subjects and to verify the } \\
\text { possible exis-tence of a } \\
\text { correlation between TMD } \\
\text { severity and cervical spine } \\
\text { changes viewed on radio- } \\
\text { graphs. }\end{array}$ & RDC/TMD & $\begin{array}{l}\text { Evaluation of the craniocer- } \\
\text { vical posture by radiographs } \\
\text { (X-Ray Heliphos D, India) } \\
\text { to determine different angles } \\
\text { (HCA, LCA, APA, OAD, } \\
\text { ATD) }\end{array}$ & $\begin{array}{l}\text { Radiographic evaluation showed that only APA } \\
(\mathrm{p}=0.002) \text { and ATD }(\mathrm{p}<0.001) \text { showed signifi- } \\
\text { cant differences between the TMD Group and } \\
\text { CG. } \\
\text { For the HCA, LCA, and OAD, no significant } \\
\text { differences (HCA: } \mathrm{p}=0.807 \text {; LCA: } \mathrm{p}=0.333 \text {; } \\
\text { OAD: } \mathrm{p}=0.839) \text { were found between CG and } \\
\text { TMD Group. } \\
\text { The results of this study suggest that head and } \\
\text { body posture could be related to the initial onset, } \\
\text { development, and perpetuation of TMD and } \\
\text { that these patients tend to exhibit cervical spine } \\
\text { hyperlordosis. }\end{array}$ \\
\hline
\end{tabular}

APA: Atlas plane angle; ATD: Anterior Translation Distance; CCA: Craniocervical Angle; CCD: Cervical Spine Dysfunction; CCDI: Craniocervical Dysfunction Index; CG: Control Group; CLA: Cervical Lordosis Angle; CMI: Cervical mobility Index; CVA: Craniovertebral angle referent to flexion-extension position of the head; F: Female; FHPA: Forward Head Posture Angle; HCA: High Cervical Angle; LCA: Low Cervical Angle; M: Male; MG: Migraine; MRI: Magnetic Resonance Imaging; OAD: Occipital-Atlas Distance

healthy controls [15].

In general, results were consistent among studies assessing craniocervical angle. Patients with TMD showed alterations in craniocervical angle in most of the studies, but no differences between TMD and healthy controls were found in any study nor association between head and neck posture nor hyoid bone position with TMD [13, 16-21]. However, a greater cranio-cervical distance in patients with TMD [14], lumbar lordosis differences between migraine and healthy controls (but no differences in migraine patients with or without TMD) [15], disc displacement differences between TMD and healthy subjects [17], and an increased ANB angle in TMD patients compared with controls [19].

\section{Discussion}

The main finding of this systematic review was that most studies reported that TMD is not associated with craniocervical angle, $\mathrm{C} 0-\mathrm{C} 1$ distance, $\mathrm{C} 1-\mathrm{C} 2$ distance norhyoid bone position. The studies included in this review did not considered important features regarding the sample size estimation to be considered as representative nor the validity and reliability of the measurement procedures. Therefore, future studies should consider reporting validity and reliability estimates of the procedures and including larger sample sizes for improving the methodological quality of the studies.

To the best of our knowledge, the last systematic review assessing the association between TMD and head and neck posture was conducted in 2006 [4]. Based on recent and available literature to date, we found 9 studies assessing the association between TMD and head and neck posture $[13,21]$ compared to the only 2 studies in the previous systematic review [4].

Up to the date, the association between TMD (either muscular or intra-articular etiology) with head and neck posture was unclear due to the lack of studies without methodological defects (e.g., TMD diagnosis, sample size, and assessment procedures). Although some methodological defects were found, the studies included in this systematic review fixed several methodological defects reported in the previous systematic review conducted by Olivo et al., [4] including consistent TMD diagnosis (DC/TMD or RDC/TMD criteria).

The studies included in this systematic review assessed the head and neck posture by radiographic analysis and/or photogrammetry. Gadotti et al., [22] conducted one study for assessing the reliability of both methods to assess the craniocervical posture. Results showed a good to excellent intra- and inter-rater reliability estimates on both methods for measuring angles to quantify the craniocervical posture, but visual assessment showed poor agreement between raters. Although not all the studies included in this systematic review reported the validity/reliability of the procedures, all used at least one of these methods for the head and neck posture assessment and avoided the visual assessment.

Most of the studies included in this systematic review are consistent with the lack of association between craniocervical angle and TMD. Barbosa et al. [13] reported that $47.5 \%$ of subjects with TMD presented this alteration, but no differences with healthy subjects were found; Ferreira et al. [15] reported that the craniocervical angle was not different in migraine patients with and without TMD; de Farias Neto et al. [16] assessed independently the higher and lower cervical angle finding no differences between TMD and healthy populations; and Saddu et al. [18], Weber et al. [20] and Rakesh et al. [21] neither found relationship between head posture and TMD. However, when combined a reduction of this angle with an increase of the ANB angle [19] or assessing the anterior translation distance of the head [14, 16, 21], differences were found between TMD and healthy subjects.

Also, the included studies were consistent with the association between TMD and the hyoid bone position [13,17, 19]. Although Barbosa et al. [13] reported a $62 \%$ of altered hyoid bone position, 
no differences were found compared with healthy subjects. Similar results were found in the studies conducted by Matheus et al. [17] and Giacomo et al. [19].

Just one study assessed disc displacement differences between patients with TMD and healthy subjects[17], ANB angle[19] and cervical lordosis [20]. Therefore, even if differences were found between patients with TMD and healthy people, more studies are necessary to conclude if these features are clearly associated or not with TMD.

Finally, there are some limitations of the current systematic review. First, we have only included articles written in the English language, so we may have missed some relevant studies published in other languages. Furthermore, we did not include those studies which were unpublished. Secondly, although we used a comprehensive tool for the assessment of the methodological quality ofreliability and validity studies, this tool was not validated for assessing observational studies including patients with TMD. Therefore, some relevant findings for head and neck posture in patients with TMD could have been missed, although this is unlikely. Lastly, due to the variability of the statistical estimates, populations and procedures, a meta-analysis could not be conducted.

\section{Conclusion}

We found in this systematic review that altered craniocervical angle, hyoid position, C0-C1 distance and C1-C2 distance could be found both in healthy and TMD populations. More high-quality with a proper TMD diagnostic criteria, sample size and valid and reliable assessment procedures are needed to confirm these findings and controversial features associated with TMD including differences in disc displacement, ANB angle and cervical lordosis.

\section{Highlights}

- Craniocervical angle, hyoid bone position and C0-C1-C2 distances are not associated with TMD

- Most of the included studies presented methodological quality defects including sample size and validity/reliability information of the assessment procedures

- There is not enough evidence to confirm the association between TMD with disc displacement, ANB angle nor cervical lordosis.

\section{Clinical Significance}

Altered clinical findings in craniocervical angle, hyoid position or distance between cervical segments should not be considered to make irreversible treatment decisions since the current evidence found that these features are not associated with TMD.

\section{References}

[1]. La Touche R, París-Alemany A, von Piekartz H, Mannheimer JS, FernándezCarnero J, Rocabado M. The influence of cranio-cervical posture on maximal mouth opening and pressure pain threshold in patients with myofascial temporomandibular pain disorders. Clin J Pain. 2011;27(1):48-55. Pubmed
PMID: 20733480.

[2]. Nejati P, Lotfian S, Moezy A, Nejati M. The study of correlation between forward head posture and neck pain in Iranian office workers. Int J Occup Med Environ Health. 2015;28(2):295-303. Pubmed PMID:26182924.

[3]. Joy TE, Tanuja S, Pillai RR, Dhas Manchil PR, Raveendranathan R. Assessment of craniocervical posture in TMJ disorders using lateral radiographic view: A cross-sectional study. Cranio. 2019;1-7. Pubmed PMID:31516098.

[4]. Olivo SA, Bravo J, Magee DJ, Thie NM, Major PW, Flores-Mir C. The association between head and cervical posture and temporomandibular disorders: a systematic review. J Orofac Pain. 2006;20(1):9-23.Pubmed PMID:16483016.

[5]. Manfredini D, Lombardo L, Siciliani G. Temporomandibular disorders and dental occlusion. A systematic review of association studies: end of an era?. J Oral Rehabil. 2017;44(11):908-923. Pubmed PMID:28600812.

[6]. Schiffman E, Ohrbach R, Truelove E, Look J, Anderson G, Goulet JP, et al. Diagnostic Criteria for Temporomandibular Disorders (DC/TMD) for Clinical and Research Applications: recommendations of the International RDC/ TMD Consortium Network* and Orofacial Pain Special Interest Group $†$. J Oral Facial Pain Headache. 2014;28(1):6-27. Pubmed PMID:24482784.

[7]. Flores HF, Ottone NE, Fuentes R. Analysis of the morphometric characteristics of the cervical spine and its association with the development of temporomandibular disorders. Cranio. 2017;35(2):79-85. Pubmed PMID:27077255.

[8]. Baldini A, Nota A, Cozza P. The association between Occlusion Time and Temporomandibular Disorders. J Electromyogr Kinesiol. 2015;25(1):151-4. Pubmed PMID:25218790.

[9]. Rocha CP, Croci CS, Caria PH. Is there relationship between temporomandibular disorders and head and cervical posture? A systematic review. J Oral Rehabil. 2013;40(11):875-881. Pubmed PMID:24118029.

[10]. Moher D, Liberati A, Tetzlaff J, Altman DG, Group TP. Preferred Reporting Items for Systematic Reviews and Meta-Analyses: The PRISMA Statement. PLoS Med 2009; 6: e1000097.

[11]. Greenhalgh T. How to read a paper: the Medline database. BMJ 1997; 315: 180-3.PubmedPMID: 9251552.

[12]. Booths A. Brimful of STARLITE: toward standards for reporting literature searches. J Med Libr Assoc 2006; 94:421-30.PubmedPMID:17082834.

[13]. Barbosa M, Costa O, Leite P, De Sousa I, Seabra G. Cervical posture analysis in dental students and its correlation with temporomandibular disorder. Cranio. 2018;36(2): 85-90.PubmedPMID:28274183.

[14]. Souza J, Pasinato F, Correâ E, Da Silva A. Global body posture and plantar pressure distribution in individuals with and without Temporomandibular disorder: A preliminary study. J Manipulative Physiol Ther.2014;37(6): $407-$ 414.PubmedPMID:25108750.

[15]. Ferreira M, Bevilaqua D, Dach F, Speciali J, Gonçalves M. Body posture changes in women with migraine with or without temporomandibular disorders. Braz J Phys Ther. 2014;18(1): 19-29.PubmedPMID:24675909.

[16]. de-Farias-Neto JP, de-Santana JM, de-Santana-Filho VJ, Quintans-Junior LJ, de-Lima-Ferreira AP, Bonjardim LR. Radiographic measurement of the cervical spine in patients with temporomandibular dysfunction. Arch Oral Biol. 2010;55(9):670-8. PubmedPMID:20591410.

[17]. Matheus RA, Ramos-Perez FM, Menezes AV, Ambrosano GM, HaiterNeto F, Bóscolo FN, de Almeida SM. The relationship between temporomandibular dysfunction and head and cervical posture. J Appl Oral Sci. 2009;17(3):204-8. PubmedPMID:19466252.

[18]. Saddu SC, Dyasanoor S, Valappila NJ, Ravi BV. The Evaluation of Head and Craniocervical Posture among Patients with and without Temporomandibular Joint Disorders- A Comparative Study. J Clin Diagn Res. 2015;9(8):ZC55-8. PubmedPMID:26436048.

[19]. Di Giacomo P, Ferrara V, Accivile E, Ferrato G, Polimeni A, Di Paolo C. Relationship between Cervical Spine and Skeletal Class II in Subjects with and without Temporomandibular Disorders. Pain Res Manag. 2018;2018:4286796.PubmedPMID:30410638.

[20]. Weber P, Corrêa EC, Ferreira Fdos S, Soares JC, Bolzan Gde P, Silva AM. Cervical spine dysfunction signs and symptoms in individuals with temporomandibular disorder. J Soc Bras Fonoaudiol. 2012;24(2):134-9. PubmedPMID:22832680.

[21]. Rakesh N, Yashoda B, Jatti D, Nagi R. Assessment of cervical spine postural disorders in patients with temporomandibular dysfunction: a radiographic evaluation. Oral Radiol. 2014;30(1): 38-44

[22]. Gadotti IC, Armijo-Olivo S, Silveira A, Magee D. Reliability of the craniocervical posture assessment: visual and angular measurements using photographs and radiographs. J Manipulative Physiol Ther. 2013;36(9):619-25. 